\title{
日本語から韓国語へ移行する学習者達 \\ 一香港の成人学習者へのインタビューからー \\ The processes of changing the target language from Japanese to Korean: \\ Interviews with Adult Learners in Hong Kong
}

\section{瀬尾 悠希子 \\ 大阪大学大学院博士後期課程}

\section{要旨}

韓国のポップカルチャーに端を発した韓国語学習人気が、香港など様々な地域にお ける日本語学習者減少の原因であると考えられている。しかし、学習者が日本語から 韓国語へ目標言語を変えるプロセスはこれまで明らかにされておらず、韓国語学習を 始めることが日本語学習をやめることと、どのような関係にあるか定かではない。

本調査では、香港の成人学習者 5 名へのインタビューから、目標言語を日本語から 韓国語へ変えた過程を質的に探った。その結果、調査協力者達は韓国語を学ぶために 日本語学習をやめたわけではないことがわかり、韓国語学習ブームが日本語学習をや めることに直接影響しているわけではないことが窺えた。さらに協力者達は、ライフ サイクルや日本語学習の捉え方の変化とともに学びのありかた自体も変容し、日本語 教育機関をやめていることが明らかになった。学習者の多様な学びを支えるためには、 教室や学校教育といった枠組みから脱却し、日本語教育をより柔軟に捉えなおすこと が求められている。

キーワード

日本語学習、韓国語学習、目標言語の移行、多様な学び、生涯にわたる学び 


\section{日本語から韓国語へ移行する学習者達 \\ 一香港の成人学習者へのインタビューからー}

\section{瀬尾 悠希子 大阪大学大学院博士後期課程}

\section{1. 本調査の背景と目的}

香港の日本語学習人気は非常に高く、日本語は英語の次に最もよく学習されている 言語とされてきた（宮副ウォン他，2003）。国際交流基金の『日本語教育機関調査』に よると、香港の日本語学習者数は 1980 年代以降増加の一途をたどり、2006 年度には 世界第 8 位となる 32,959 人に達した。しかし、その後の 2009 年度、2012 年度の調査 では連続して減少し、2012 年度は 2006 年度から 31.6\%減の 22,555 人となった（国際 交流基金，2013，p. 34）。特に学校教育以外での減少が著しく（p. 35）、学習者の減少 は香港の「日本語教育上最も大きな問題」（p. 35）として報告されている。

一方、香港では韓国語学習が近年人気となっている。Kim（2010）によると、2000 年前後から香港の高等教育機関や大学付属生涯学習機関で次々に韓国語プログラムが 創設され、学習者数が年々増加しているという。このような韓国語人気の背景には、 政治経済的要因よりも、韓流と呼ばれる 2000 年以降の韓国ポップカルチャー人気があ るとKim は指摘している。

韓国のポップカルチャーへの関心が高まったことによる韓国語学習ブームは、日本 語学習者減少の一因になっていると日本語教育関係者の間で考えられている（国際交 流基金, 2013; 宇田川他，2014）。韓国文化人気が日本語学習者減少の一因である／将 来一因になり得るという指摘は台湾(国際交流基金，2013，p. 33)、インドネシア (p. 39)、 オーストラリア（p.66）でもなされており、韓国のポップカルチャー人気が日本語学 習者減少と直接結びついていると考えられているようである。筆者も、韓流によって 日本語学習者が韓国語に流れているという嘆きを周囲の日本語教師からしばしば耳に し、「韓国ポップカルチャー人気による韓国語学習者増加 $\rightarrow$ 日本語学習者減少」という 言説は、日本語教育関係者の間で広く流布していると考えられる。

上記の言説では、韓国語学習者増と日本語学習者減という二つの現象が関連づけて 述べられているが、そこにあるはずの学習者の意識や感情、学習者と社会との関係は じゅうぶんに見えていない。また、その点を調査した研究も管見のかぎり見当たらな い。そこで本稿では、学習者達がなぜ、どのように日本語から韓国語へと目標言語を 変えたのかを学習者の視点から明らかにし、韓国語学習を始めることが日本語学習を やめることと、どのような関係にあるかを考察する。そして、かれらの日本語学習を 支援するために日本語教育に携わる者は何ができるのかを議論したい。

1 http://www.jpf.go.jp/j/project/japanese/survey/result/index.html（2016 年 1 月 23 日）

論文 


\section{2. 理論的枠組み}

長年、第二言語/外国語学習に対する学習者の意識は、個々人の心理的問題として 動機づけの概念を用いて計量・分類されてきた（Dörnyei \& Ushioda, 2011）。しかし、 Norton（2000）は、学習動機の概念では学習者と社会の複雑な相互関係を捉えきれな いとし、学習動機に代わって、文化資本を増大させたりアイデンティティを構築する ための投資という概念を用いて、学習者の意識を捉えることを提案した。

さらに、Kubota（2011）は、成人学習者にとっての外国語学習は投資ではなく、社 会経済的地位を確立した娛楽としての余㗇活動であり、楽しみの消費であると指摘し ている。Kubotaによると、余㗇活動にはシリアスな余㗇活動とカジュアルな余㗇活動 (Stebbins，2007）がある。シリアスな余暇活動はスキルや知識の体系的な獲得に醍醐 味を見出している趣味活動であり、カジュアルな余暇活動とは快楽や自己満足を最大 の目的とした感覚的な喜びの趣味活動である。Kubota の調查では、日本で英会話学校 に通う人達が、学習仲間と交流寸る喜びや白人への憧れなどからカジュアルな余暇活 動として英語を学び、言語能力向上を目的とするより現実・空想上の社交から得る満 足感を消費していると報告されている。

本調査を行った香港でも、学校教育以外で余暇活動として日本語を学ぶ者が多く、 日本語を理解したり他者とつながったりする喜び（瀬尾，2011a；2011b）や、他者と 違う特別な自分の象徵（瀬尾・山口, 2014）、自己の成長の象徵（三國, 2013）などの 意味合いを日本語学習に見いだしていることが明らかになっている。

\section{3. 調査の概要}

\section{1 調査の認識枠組み}

本調査では日本語と韓国語学習への学習者の意識の変化を捉え、日本語から韓国語 一移行するプロセスを質的に探った。流動的かつ多層的な学習者の意識の変化と、そ の変化に影響を及ぼした経験を明らかにするには「人々にとっての事象や行為の意味 を解釈し、その場その時のローカルな状況の意味を具体的に解釈し構成していく」(秋 田・藤江, 2007, p. 9) 質的調查法が適している。なかでもストーリーを用いた研究は、 経験の意味のニュアンスや豊かさが表現でき（Aoki，2009）、学習者の言語学習に対す る意識を複雑なままに理解するのに有用である。

ストーリーを用いた研究は、Analysis of Narratives と Narrative Analysis に分 類され（Polkinghorne，1995）、Bruner（1986）が区別した論理実証モードと物語モー ドという二つの思考様式にそれぞれ対応している。Analysis of Narrativesでは、論 理実証モードのもとでストーリーからカテゴリーを抽出し、一般化が目指される。 
一方、Narrative Analysis では物語モードの思考様式によって出来事と出来事をつな ぐ筋を探り、統一あるストーリーを記述する。そして、ケースの複雑性、個別性を描 き出すのである。本調査は、日本語から韓国語へ移行した学習者の感情や意識を複雑 で個別的なものとして捉え、理解することを目指すため、Narrative Analysis を行う。

\section{2 調査の場所と協力者}

本調査は香港にある生涯学習機関 A 学校で行った。A 学校では 2006 年度を境に日本 語学習者が減り続け、調査を行った 2014 年度は当時の半分以下になっていた。一方、 韓国語プログラムは 2003 年度の創設以来学習者が増え続け、この 10 年余りで約 5 倍 に増加している。2014 年度の学習者数は韓国語が日本語を上回っている。

調査協力者はA 学校で韓国語を学んでおり、かつて日本語も学んだことのある成人 学習者 5 名である。全員、調査時は A 学校の韓国語プログラムに在籍していたが、日 本語は A 学校以外の機関で学んだ者もいる。調査協力者達とは、本調査を行うにあた り韓国語プログラムの教員からの紹介で知り合ったため、筆者と調査協力者達はイン タビュー時まで面識がなかった。

\section{表 1 調査協力者のプロフィール}

\begin{tabular}{|l|l|l|l|l|}
\hline 仮名 & 性別 & 年齢 & 日本語学習年数 /機関 $/$ 日本語能力試験 & $\begin{array}{l}\text { 韓国語 } \\
\text { 学習年数 }\end{array}$ \\
\hline Anne & 女 & 30 代 & 1 年 $/$ 語学学校 $/$ 受験経験無 L & 1 年 \\
\hline Be11 & 女 & 20 代 & 3 年 $/$ 語学学校 $/ \mathrm{N} 3$ & 2 年 \\
\hline Carmen & 女 & 20 代 & 4 年 $/$ 専門学校、日本の日本語学校、A 学校 $/ \mathrm{N} 1$ & 3 年 \\
\hline Doris & 女 & 20 代 & 6 年 $/$ 大学、日本交換留学 $/ \mathrm{N} 1$ & 2 年 \\
\hline Emily & 女 & 40 代 & 10 年以上 $/ \mathrm{A}$ 学校 $/ 2$ 級 & 4 年 \\
\hline
\end{tabular}

\section{3 調查の方法}

事前にある程度の学習背景を知るため、インタビューに先立ち、母語、日本語・韓 国語の学習年数、学習機関、使用教材、日本語能力試験、韓国語能力試験について Eメールでたずねた。その後、2014 年 9 月に 1 時間から 1 時間半程度の個人インタ ビューを A 学校の教室で 1 回ずつ行った。半構造化インタビューによって、日本語と 韓国語の学習動機や学習機関内外での学習経験とそれについての考えを中心に聞き、 調査協力者の同意を得て録音した。インタビュ一前に英語か日本語を選択してもらい、 Anne さんとBe11 さんは英語、Carmen さん、Dorisさん、Emily さんは日本語で行った。 ただし、日本語で行った場合も英語で発言を補うことも時々あった。 


\section{4 分析の方法}

Polkinghorne（1995）を参考に、分析を行った。まず、録音したデータを逐語的に 文字化し、複数回読み込んだ。その後、日本語・韓国語の学習動機と学習経験、それ らについての考えの部分を抜き出し、出来事やトピックにまとめた。そして、まとま りの内容を一文で書き表して項目（表 2 参照）とし、時系列に配置した。その後、現 在の調查協力者の姿を同定し、どうやってそこに至ったのかという視点で項目同士の 関係を遡及的に検討して項目間をつなぐ筋を探った。最後に、日本語を学習し始めた ときから現在までのストーリーを記述した。

\section{表 2 項目例（Anne さん）}

・働き始めて、新しいことを学びたくなった

・特に目標はなかった
・長く日本語を勉強している友達が いたから、やってみようと思った

・仕事量が増え、残業が多かった

\section{4. 分析}

本章では、調査協力者達の日本語と韓国語の学習経験のストーリーを提示する。ス トーリーは、協力者と調査者の相互交流の中で作り出されるものであるため、現場の 記述や語り方の考察、調査者のストーリーも書くことが望ましいとされている（森岡， 2013）が、紙幅の都合上、本稿ではできるかぎり調査の詳細を記述し、データを直接 引用することで信憑性を高めることに努めた。短い引用は「」、長い引用はインデント で示す。また、調査者である筆者のストーリーに代え、筆者の日本語教育観の変化を 考察に含める。英語のインタビューデータは全て日本語に翻訳した。

\section{1 Anne さん}

就職して何か新しいことを学びたくなった Anne さんは、言語を学ぶと記憶力や論理 力を養えて良いと考え、友達と一緒に日本語を習い始めた。日本のファッション雑誌 をたまに読む程度で、日本の文化が特別好きだったわけではないが、長年日本語を勉 強している友達がいたので、「やってみてもいい」と思い、その友達が通っていた語学 学校に通い始めた。日本語を勉強するうえで何か目標があったわけではなく、「単なる 興味」だった。だが、習い始めてしばらくは面白いと思ったものの、だんだんコース の内容が難しくなり、仕事の忙しさも相まって学校をやめた。 
筆者：どうして日本語を勉強しないことにしたんですか。

Anne：実は 1 年ぐらい勉強したんです。最初は面白いと思っていたんですが、 だんだん良くなくなりました。複雑で難しくなって、私達はついてい けなくなったんです。だから、そこで終わりにしました。私の仕事も 忙しくなって、私達は一緒にコースをやめました。

筆者：なるほど。じやあ、仕事量がちょっと…

Anne : はい。

筆者：あなたの仕事量が増え…

Anne：理由は 2 つです。私の仕事量と、コースがとても、日本語のコースが 私にとってとても難しくなったのでやめました。

その後 Anne さんは転職して時間に余裕ができたので、もう一度何か習おうと思った。 しかし、「複雑でフラストレーションを感じた」と述べるように、日本語に対するフラ ストレーションが溜まっていたので、韓国語を学ぶことにした。当時流行し始めてい た韓国ドラマや $\mathrm{K}-\mathrm{pop}$ が好きだったのも、韓国語を選択した理由である。

筆者：どうしてそんなにフラストレーションを感じていたんですか。

Anne：たぶん日本文化にそんなに興味がなかったからだと思います。音楽と かドラマとかに。そして、ご存知だと思いますが、今は韓国文化がと ても流行っています。実は、私は韓国の音楽やドラマがとても好きな ので、ちょっとやってみたいと思いました。

Anne さんは現在通っている韓国語プログラムは「とても体系だっていて、ちゃんと コースについていけていい」と述べている。それに、試験もあるので勉強のペースメ 一カーになる。韓国語は趣味で勉強しているだけだが、試験で良い点数を取ると嬉し いので、勉強を続けるつもりである。

筆者：日本語は難しいからやめたと言いましたね。韓国語は? 難しいですか。

Anne：実は、授業の後にかなり長い時間を勉強に費やしているんです。仕事 の後は 1 日か 2 日、週末は 1 日。とても時間がかかります。たくさん 時間を費やします。でも、試験で良い結果が出ると、ああ続けたほう がいいなと思います。

\section{4. $2 \mathrm{Bell}$ さん}

Be11 さんは大学の選択科目で日本語を選んだ。日本のドラマや日本旅行が好きだっ たことに加え、ルームメイトが日本人だったことが授業を取るきっかけだった。しか し、他の科目の勉強が忙しくて、選択科目として登録したものの、すぐにやめてしま つた。その後、大学 3 年生のとき、語学学校で再び日本語を習い始めた。Be11 さんは 日本人の友達と話したり、日本のドラマを見たり、旅行で日本語を使いたかったので、 
会話の上達を目的としていた。しかし、通っていた学校は文法重視で会話練習が少な く、話す力がつかないと感じた。

Be11：日本人じゃなくて日本語が話せない香港人の友達と日本に旅行したら、 かれらはわたしが日本語を話せると期待するんです。でも、私は一言 も話せませんでした。

筆者：それは興味深いですね。

Be11：私は学校の影響が強いと思うんです。学校での練習が。だって、私た ちは口頭試験がなかったし、口頭練習もあまりしなかったんです。

そこで、Be11 さんはこの学校と並行して別の会話重視の語学学校にも通った。だが、 クラスの学生間のレベル差が大きく、初級のBe11 さんは不満だった。

Be11：学生のレベルが違いすぎて、クラスはあまり良くないと思いました。日 本語を流暢に話せる人もいました。ある女の子は日本留学を予定してい ると聞きました。だから、レベル差が大きすぎました。私はゼロレベル でしたから、もっと基本的なことを学びたかった。でも、レベルが違い すぎたし、先生がたくさん話していました。だから、口頭能力で得るも のはあまりなかったです。そして、最後は潮時だと思いました。

ちょうどこの頃、韓国ドラマをよく見るようになった。日本語が話せるようになら ないことに不満を抱いていた Be11 さんは「全部最初からやり直したほうがいい」と考 え、日本語をやめて韓国語を始めることにした。たとえ日本語を別の学校で初級から やり直しても、文法は既に知っているので「時間の無駄」だと思った。今はA学校で 韓国語を勉強しており、会話も練習できるから良いと思っている。

\section{3 Carmen さん}

Carmen さんは、専門学校に進学することになり、自分は「話すのが好き」だから、 語学が向いているだろうと考えた。そして、日本語を勉強すると香港にたくさんある 日系企業に就職しやすくなるかもしれないと考え、日本語を専攻することにした。

筆者：そのときはどうして韓国語を勉強しなかったんですか? 専門学校では。 Carmen：実はしたかったんですけど、(韓国企業が）あんまりないんです。そ のときは。

筆者：あ、まだ少ない。

Carmen：はい、まだ少ないですから。それで日本の会社が香港でたくさんありま すから、やっぱり卒業してから就職のため、日本語を選びました。

専門学校では、月曜日から金曜日まで授業があった。最初から「あいらえお」を 1 日で終えるなど、勉強は大変だったが、「速く勉強できるのはいい」ことだし、「勉強 が楽しかった」。香港ではなかなか日本語を話す機会がないため、「やっぱり日本へ行 
かないと上手にならない」と感じ、専門学校を卒業後、大阪の日本語学校に 1 年間留 学した。日本語学校では他の国からの留学生と日本語で話さざるを得ず、話すのが上 手になった。また、日本滞在中に日本語能力試験 N1 を受けて、合格した。

香港に戻ってきてから、Carmenさんは希望じおり日系企業に就職した。仕事では日 本語を話す機会はあまりないが、お客さんに丁寧にメールを書かなければならず、う まく書けないので、ビジネス日本語のクラスを取ることにした。しかし、そのクラス はあまり役に立たなかった。Carmenさんは自分で文章を考えて書く力を身につけたか ったのに、授業では主にインターネットで資料を探してくる方法を習うだけだったの で、期待していたものと少し違ったのだ。

Carmen さんは日本語のクラスは「もう取らない」と言う。仕事で契約書を翻訳でき るともっといろいろな仕事を任せてもらえるようになると思い、翻訳のクラスは取り たいと考えているが、人気がありすぎて取れないそうだ。その他に興味があるクラス はなく、クラスを履修する必要性もそれほど感じていない。

Carmen：もう充分です。何年か勉強してですから。なんとなくできるかなあ と hhh 思って。

筆者：hh、そうですね。

Carmen：本当に足りないときは、その時は本屋で本を見てもわかるじゃない ですか。

筆者：自分で。

Carmen：自分で勉強して、はい、勉強。

筆者：日本語ももし自分で勉強しようと思ったらできる。

Carmen：そうです。

筆者：ときどき今も自分でこう調べたりすることはありますか?

Carmen：ありますよ。単語わからないときもあるしー、文法もそうです、は い。わからないときは自分で本で探します。と、ネットも。

K-pop が好きになり歌詞を理解したいと思い、専門学校を卒業して日本へ行くまで の間に少し韓国語を習っていた。留学中は韓国語の学校は休んでいたが、香港に戻っ てきてから再開した。K-pop への興味から始めた韓国語だったが、最近は「前のとき と比べると、今、ただことば勉強したい気持ち」に変わってきたという。

Carmen：今は、なんか年が取ったから、hhhhh、あまり? 昔よりちょっと、 （K-pop に対して）まあ普通の気持ちで、hh。

筆者： 年取ったは、Carmenさんが年取った?それとも歌手が年取った?

Carmen：私が年取ったから、あのう、もうせっかく勉強し始めたから、やっ ぱり上手になりたい? そういう気持ちで、韓国語勉強してます。

韓国語を将来仕事に役立てようとは考えていないが、「能力が認められるとういう感 じ」がするので、もっと文法を勉強して韓国語検定を受けたいと考えている。 


\section{4 Doris さん}

Doris さんは、中学生のときに夏休みの間だけ語学学校で日本語を勉強した。ジャ ニーズのアイドルやドラマ、雑誌が好きだったので、それらをわかるようになりたい と思ったのがきっかけだ。

そして、大学に入って「日本語勉強するともつといい会社へ就職できるかな」と思 い、日本語を専攻した。それに、ドラマで見ていた日本へ留学するのも夢だった。そ して大学 3 年生のときに 1 年間日本へ留学した。留学中は日本語が「はやく上手にな って、日本人の友達もできて楽しかった」。

就職活動では日系企業にも応募したが、書類作成など「つまらない仕事」しかさせ てもらえないようだったので、将来のキャリアに役立つ仕事がある会社に入った。

筆者：じやあ今のほうがもっと、まあもっと将来の役に立つ?

Doris : はい。

筆者：どんな仕事なんですか? 事務じゃない、営業?

Doris：あ一、中国の、えー…なんていう、えー中国のお客様を調査します から、中国や中国人のお客様から学ぶことができます。だから、将来 のキャリアを考えるとこちらのほうがいいんです。

筆者： ああ、日本のカルチャーより中国のカルチャーのほうが

Doris : 香港ではとても大切。

日本語を仕事で使う可能性はなくなったが、大学では日本語能力試験 N2 までしか合 格しなかったので、せっかくなら N1にも合格したいと思い、語学学校の N1 対策クラ スで勉強を続けた。このクラスでは毎回 5 つぼ文法を習い、とても面白かった。授 業に加えて、自分でも参考書を買って勉強した。そして、一発で合格した。

N1に合格してしまうと、日本語を勉強する目標がなくなった。また、勉強できる場 所もわからなかった。

筆者： 1 級（N 1 ）を取ったあとのゴールは

Doris：そのゴールは、hh、なかったから、韓国語 hh 勉強しました。

筆者： じゃあ目標も終わったから。

Doris：でも、授業もなかった、あんまり1級の後のクラスがなかった。

筆者：クラスがなかった。

Doris：どこで勉強するのがわからないので。

Doris さんは、ちょうどN1に合格した辺りから、少女時代という韓国のアイドルグ ループが好きになった。そして、だんだん韓国語に興味が出てきた。日本語は、自分 でドラマを見て続けられるので、韓国語を勉強することにした。 
筆者：日本語はもうぜんぜん勉強していませんか。

Doris : うーん、ドラマとか見ています。はい。

筆者：文法とか言葉とかはあまり。

Doris : hh、あまり。

筆者：じゃあ、もうそういうのを勉強したい気持ちはもうあまりないんですね。 Doris：そうですね。もう満足。

韓国語も仕事では使わないので、「興味だけ」で勉強している。ドラマがわかるよう にしばらく勉強を続けるつもりだ。

\section{5 Emily さん}

Emily さんは「日本のドラマが大好きで」、字幕なしで見られるように日本語の勉強 を始めた。次第に日本へ旅行したり日本人の友達ができたりして、ドラマ以外にも「次 第に興味を持って」いった。日本語は 10 年以上ずっとA 学校で学んでいる。A 学校は 宿題があるので勉強できるし、Emily さんは「負けず嫌い」だから試験のためにも一 生懸命勉強した。また、うちでは「まるで日本」にいるように、毎晚ドラマを見たり ラジオを聞いたりしていた。そして、気になった表現をメモして調べたり繰り返して 言ってみたりしていると「だんだん日本人ぽくなるって（感じて）嬉しかった」。学校 で勉強する日本語と「日常の生活（で使われる日本語）はちよっと離れて」いるが、 「学校行かないと、日本語の文法とかわからない」と思っている。

このようにして 10 年ぐらいA 学校で日本語を学んできたが、そのうち取りたいクラ スがなくなってしまったので、A 学校の友達と二人で家庭教師の先生に日本語を習う ことにした。

筆者：それはどうしてA 学校をやめて、その先生に変えたんですか？

Emily : いや、最後の、あのう翻訳とビジネス（のクラス）。あとは、ドラマ (のクラス) もあったけど、昔のドラマですから、ちょっと興味がい まいちな感じ?ですから、hhh。うーん、続くのはなれなかった。

筆者：じやあ、もう家庭教師のほうが

Emily：そうそうそう。だいたいお喋り会とか、みたいな?

筆者：あ、でも勉強にはなったですか?そのお喋り会

Emily：そうですねー。せめて会話は、今もうできる、hh、から、あのう、た ぶん毎回、一つや二つの表現を覚えるなら、いいだと思いますね。

テレビや雑誌を教材として家庭教師とお喋りし、表現をいくつか覚えるというスタ イルで 3 年ぐらい続けた後、「教材が少なくなって」終わりにした。その頃、友達が 
マンションの隣の部屋に住む日本人と親しくなり、「じゃあ、お茶会でもやろう」とい うことになった。今はその日本人とときどき会ってお喋りをしている。だから、Emily さんとしては日本語学習をやめたという意識はない。

筆者： 家庭教師をやってる間ぐらいに、韓国ドラマに興味を持って、そのあ と韓国語に変えた。

Emily：そうですね。でも、今も友達の家で日本人の友達があの、会話を続け るからー、まあ、やめるわけではないですよ hhhhh

筆者：あー、じやあ別に自分の中では日本語をやめて韓国語じやなくて //Emily：そうそう//、まあ家庭教師はしないけど、自分で話したり //Emily：そうそうそう//、う一ん

Emily：今も日本語のドラマを見たり、面白い台詞があったら繰り返します。 筆者：じやあもう学校へ行く必要がないということですねー。

Emily：私の場合は今ですね、文法はだいたい習ったことがあるから、学校は 行かなくても大丈夫かなあと思って。

Emily さんは日本語を「ただのレジャー」として学んでいるから、今後学校でクラ スを取るとしても、文法を学ぶようなクラスは必要ない。

筆者：そっか…じやあ将来日本語を学校で勉強する予定ももう別にないで すか。

Emily : いや、もしとても面白いクラスがあればー。たぶん。

筆者：あーー、どんなクラスだったら面白いですかねえ?

Emily : 料理のクラス、ありますか?

筆者： 料理はねえ…面白そうですけどねえ……じやあやっぱり興味がある クラスが欲しい。//Emily：うーん// そのクラスは文法よりー

Emily : もつと軽いもの?

筆者： 軽いものがいい...。じあ、行ってこう楽しく日本語を話しながらー Emily：そうそうそう、試験は要らない、hhhhh。

家庭教師が終わり「新しいものを勉強したい」と思った Emily さんは、当時韓国ド ラマをよく見ていたことから、韓国語を習い始めた。昔は韓国語を聞くと「うんざり だと思った」り、「嫌な感じがあった」が、勉強しているうちに「だんだん大丈夫にな った」。韓国人の友達もできて親切にしてもらい、韓国語を勉強していて「いいことあ るかな」という気持ちに変わってきた。ただ、これまで週 1 回だったクラスが、次の レベルでは週 2 回に増えるので、「ちょっと厳しいなと思って」来年はとりあえず学校 を「ちょっと一休憩」しようと思っている。 


\section{5. 考察}

調査の結果、協力者達は韓国語学習を始めるために日本語学習をやめたわけではな いことがわかった。Anne さんと Bel1 さんは、日本語の難しさ・仕事の忙しさ・望む 力が身につかないという挫折を経験して、まず日本語学習をあきらめていた。その後、 言語学習のやり直しとして韓国語を選んだのである。Carmen さん、Doris さん、Emily さんは、自身の日本語能力にある程度満足し、学校での日本語学習をやめ、日本語に 代わる言語として韓国語を選択した。彼女らにとって、韓国のポップカルチャーは韓 国語選択の誘因とはなっているが、日本語学習をやめることに直結はしていない。日 本語教育関係者の間で懸念されているように、韓国語学習人気が日本語学習を継続す るかしないかに直接影響しているのではなく、何らかの理由で日本語学習をやめたこ とをきっかけに韓国語へ移行しているに過ぎないのである。

では、かれらの日本語学習を私達はどのように支援していくことができるだろうか。 協力者達のストーリーを日本語学習をやめた時点に注目しながら見直そう。

Anne さんは仕事の忙しさから勉強時間が確保できなくなり、授業につい ていけず語学学校をやめた。

・Bel1 さんは会話の上達を望んでいたが、文法重視の学校やレベル差の大 きい学校ではそれが叶わないと感じ、日本語学習を断念した。

・ Carmenさんも、仕事で必要な日本語のスキルは学校で得られず、他に取 りたいクラスも無かったため、必要なことは自分で勉強していくことに した。

・ Doris さんは、日本語能力試験 N1 合格後はドラマを見ることで日本語を 継続することにし、教育機関での学習は終えた。

・ Emily さんは、語学学校で興味があるクラスがなくなり、家庭教師や日 本人の友人とのお喋りを通して日本語を続けている。

つまり、彼女らが日本語教育機関での学習を継続していたのは、日本語学習を投資 あるいはシリアスな余暇活動として捉えていたときであり、個人的な学習目的やライ フサイクルと教育機関での学習が合致しなくなったり（Anne、Be11、Carmen）、カジュ アルな余暇活動として日本語学習を捉えるようになったとき（Doris、Emily）、日本語 教育機関をやめている。

したがって、彼女たちの日本語学習継続を支援するためには、まず学習者の学習目 的や生活スタイルを考慮した学習機会を提供することが重要である。例えば、仕事の 忙しさから日本語学習を諦めた Anne さんのような学習者には、緩やかなカリキュラム や自分のペースで学習を進められるラーニング・センターの整備など、ライフサイク ルに合った学習支援が考えられるだろう。また、個人的な学習目的と教育機関での 


\section{日本語から韓国語へ移行する学習者達 \\ 一香港の成人学習者ヘのインタビューからー}

学習に乘離があった Be11 さんや Carmenささんのような学習者へは、教育機関や教師が 学習目的を予め把握し学習中も学習状況をモニターできるシステム作りや、個別化教 授法（Tomlinson，2004）を教師が身につけることが有効だろう。

次に、カジュアルな余暇活動への支援を充実させることも重要である。Doris さん やEmily さんが教育機関をやめた後に行っているドラマの視聴やお喋りは、必ずしも 言語能力向上のみが目指されているわけではなく、一見すると“学習”には見えない かもしれない。だが、近年は規範的な言語知識の獲得や正確性の向上のみを言語学習 と捉えることが疑問視されてきており、「本質的、固定的、多義的、流動的な言語や文 化理解が交錯する中で自己の立場や言葉やアイデンティティを模索することができる 能力」（尾辻，2011，p. 28）を実践を通して学んだり、「自己変容の発見に出会い、そ の社会で生きることについて自己の立場を明確にすること」（細川, 2007, p. 12）が言 語学習であると考えられるようになってきている。言語学習をこのように捉えると、 お喋りやドラマの視聴も学びにつなげられる可能性があるとは言えないだろうか。久 保田他（2014）は、香港の社会人教育機関で言語能力伸長を目指したカリキュラムが 実施されていることを指摘しているが、日本や日本語をめぐる人々や営みが出会い対 話する場を積極的に創出し、充実させることによって、言語面に留まらない学びも広 げ深めることができるのではないだろうか。例えばEmily さんの場合、日本語教育機 関が料理教室と協働し、料理を介して他者と交わったり料理をめぐる文化を多様な視 点で捉えたりする場を作り出すことが考えられる。日本語教育者はこのとき言語知識 や技能の育成者だけではなく、場のデザイナーや、思考や感情を掘り起こしたり内省 を促したりするファシリテーターの役割も担うことになるだろう。

学校教育機関以外で生涯学習として日本語を学ぶ者が多い香港では、様々な生活を 送る学習者がおり、日本語学習の意味づけも多様で、大きく変容することも多い。か れらの生涯にわたる日本語学習を支援していくためには、様々な学びのありかたを認 め、柔軟な日本語教育を目指さなければならない。そのなかで日本語教育に携わる者 に求められているのは、言語習得のみを目指寸日本語教育からの脱却ではないだろう か。筆者は本調査を通して、自身が無意識に抱いていた日本語教育の姿を自覚するよ うになった。日本語教師として言語教育機関で教えてきた筆者は、言語習得を第一目 的として行う営みが日本語教育であるというイメージを抱いていたため、協力者達は 日本語学習を “やめて”韓国語へ移行したと考えていた。それゆえ、Emilyされん「料 理のクラスはありますか」と聞かれたときに一瞬戸惑ってしまったのである。しかし、 Emily さんにとって、日本語学習とはただ言語を習得するのではなく、日本語を用い た様々な活動を他の人々と楽しむことであった。筆者の日本語教育に対するイメージ 
は、彼女らの今も続く学びとその先にある可能性を覆い隠していたのである。筆者の 持っていたイメージは筆者だけが抱いていたわけではなく、尾辻 (2011) や細川 (2007) が問題提起しているように、日本語教育においては広く流布しているものであると考 えられる。

生涯にわたる日本語学習を支援するためには、教室空間で知識や能力を教えるとい う営みに閉じるのではなく、教室を超えた学習環境の整備や言語能力の習得を第一義 としない学びの支援を考えることにも積極的に関わる必要がある。学習者の多様な学 びを受け容れ、日本語教育という営みを柔軟に捉え直すことによって、言語学習にお いて重要とされつつも脇に置かれがちだった学習者のアイデンティティや情緒的側面 にも対応し、日本語教育が言語能力の育成だけではなく、新たな役割を通して社会に 貢献できる可能性が開けるだろう。

\section{6. むすびー多様な日本語学習を支える多様な日本語教育に向けて}

本調查は、学習者が日本語をやめて韓国語に移行したという前提で開始した。だが、 調査の結果からは、現在も日本語をめぐる学びを継続している調查協力者もいること がわかった。学習者はそれぞれの言語をめぐり、多様な学びを展開している。教育機 関で学ぶ学習者の増減のみにとらわれるのではなく、学習者の行っている様々な学び をいま一度見つめ直し、かれらにとって実りある学びを深める支援を行うことが、私 達言語教育に携わる者の責任ではないだろうか。

※ 本稿は、2014 年 11 月に開催された第 10 回国際日本語教育・日本研究シンポジウ ムでの瀬尾匡輝・室田真由見両氏との共同発表を基点とし、データを再分析したもの である。二名の查読者に加え、本研究の様々な段階で、瀬尾匡輝氏、室田真由見氏、 米本和弘氏から有益で建設的な意見をいただいた。深く御礼申し上げる。 


\section{参考文献}

秋田喜代美・藤江康彦（編）『はじめての質的研究法 教育・学習編』東京図書.

宇田川洋子他（2014）「香港の日本語学習者減少の要因」『日本学刊』17, 106-120.

尾辻恵美（2011）「メトロリンガリズムと日本語教育」『リテラシーズ』9, 21-30.

久保田竜子他（2014）「余暇活動と消費としての日本語学習」第 9 回国際日本語教育・日本研究シン ポジウム大会論文集編集会（編）『日本語教育と日本研究における双方向性アプローチの実践と可 能性』（pp. 69-85） ココ出版.

国際交流基金（2013）『海外の日本語教育の現状』くろしお出版.

瀬尾匡輝（2011a）「香港の日本語生涯学習者の動機づけの変化」『日本学刊』14, 16-39.

瀬尾匡輝（2011b）「香港の上級の日本語生涯学習者の動機づけ」『アジア日本研究』1, 11-25.

瀬尾匡輝他（2012）「なぜ日本語学習をやめてしまったのか」『日本学刊』15,80-99.

瀬尾匡輝・山口悠希子（2014）「インフォーマル・ラーニング下における日本語学習」第 9 回国際日 本語教育・日本研究シンポジウム大会論文集編集会（編）『日本語教育と日本研究における双方向 性アプローチの実践と可能性』（pp. 87-99）ココ出版.

細川英雄 (2007)「新しい言語教育をめざして」小川貴士 (編)『日本語教育のフロンティア』(pp. 1-20) くろしお出版.

三國喜保子（2013）「香港における日本語の民族言語的バイタリティー」『言語教育研究』3, 53-62. 宮副ウォン裕子・鈴木東・石秋畑（2003）「香港における日本語の社会言語的な地位」香港日本語 教育研究協会（編）『アジア太平洋地域における日本語教育と日本研究』（pp. 344-347）向日葵 出版社.

森岡正芳 (2013) 「ナラティヴとは」やまだようこ他（編）『質的心理学ハンドブック』（pp. 276-293） 新曜社.

Aoki, N. (with Kobayashi, H.) (2009). Defending stories and sharing one. In Pemberton, R., Toogood, S. \& Barfield, A. (Eds.), Maintaining Control: Autonomy and Language Learning (pp. 199-216). Hong Kong: Hong Kong University Press.

Bruner, J. (1986). Actual Minds, Possible Worlds. Harvard University Press.

Dörnyei, Z., \& Ushioda, E. (2011). Teaching and researching motivation (2nd ed.). Harlow: Longman.

Kim, H. K. (2010). Korean Language and Korean Studies in Hong Kong (1989-2009). Electronic Journal of Foreign Language Teaching, 7(Suppl. 1), 141-153.

Kubota, R. (2011). Learning a foreign language as leisure and consumption. International Journal of Bilingual Education and Bilingualism, 14, 473-488.

Norton, B. (2000). Identity and language learning: Gender, ethnicity and educational change. Harlow, UK: Longman/Pearson Education.

Polkinghorne, D. E. (1995). Narrative configuration in qualitative analysis. In J. A. Hatch \& R. Wisniewski (Eds.), Life history and narrative (pp. 5-23). London: Falmer.

Stebbins, R. A. (2007). Serious leisure. New Brunswick, NJ: Transaction.

Tomlinson, C. A. (2004). How to differentiate instruction in mixed-ability classrooms (2nd ed.). Upper Saddle River, NJ: Pearson. 